Szczecin

\title{
Stanowisko Parlamentu Europejskiego wobec Wspólnej Polityki Bezpieczeństwa i Obrony rozszerzonej UE
}

\section{Wprowadzenie}

Utworzenie w latach 50-tych XX w. Wspólnot Europejskich (WE) nadało procesowi integracji europejskiej przede wszystkim charakter współpracy ekonomicznej. Kwestie integracji w sferze bezpieczeństwa wskutek niezrealizowania projektu powołania ponadnarodowej Europejskiej Wspólnoty Obronnej (EWO) nie stały się priorytetem dla przywódców państw zachodnioeuropejskich. Nie zmieniło tego powołanie z inicjatywy Wielkiej Brytanii nowej struktury bezpieczeństwa o charakterze międzyrządowym, jaką była Unia Zachodnioeuropejska (UZE). Organizacja ta powołana 23 października 1954 r. w Paryżu na mocy układów zmieniających Traktat brukselski nie mogła wypełnić luki w sferze integracji w dziedzinie bezpieczeństwa, która powstała wskutek upadku projektu EWO. Przyczyną tego stanu rzeczy była niesamodzielność wojskowa UZE oraz podporządkowanie się strategii i polityce NATO, które stało się najważniejszą strukturą bezpieczeństwa dla państw Europy zachodniej. Odzwierciedlało to ówczesną sytuację geopolityczna, która sprawiała, że to USA poprzez istnienie NATO, stały się najważniejszym elementem zachodnioeuropejskiego systemu militarnego i gwarantem bezpieczeństwa dla państw Wspólnoty Europejskiej. Istnienie amerykańskiego parasola atomowego gwarantującego bezpieczeństwo Europie zachodniej, jak i sprzeczność interesów poszczególnych krajów WE powodowało brak zainteresowania Europejczyków w tworzeniu ponadnarodowych struktur bezpieczeństwa. Dopiero w połowie lat 80 -tych XX w. UZE zaczęło stawać się organizacją, na forum której rozpoczęła się wymiana poglądów na temat zdefiniowania na nowo europejskich interesów w dziedzinie bezpieczeństwa i obrony. Poszukiwanie europejskiej tożsamości bezpieczeństwa uległo przyspieszeniu wskutek upadku żelaznej kurtyny i załamania się bipolarnego systemu stosunków międzynarodowych. Wytworzenie się nowej sytuacji geopolitycznej w Europie, której towarzyszyło szereg konfliktów dało impuls do ustanowienia Wspólnej Polityki Zagranicznej i Bezpieczeństwa (WPZiB) jako drugiego filaru Unii Europejskiej (UE) - organizacji powołanej 7 lutego 1992 r. na mocy Traktatu z Maastricht, który wszedł w życie 1 listopada 1993 roku (por. szerzej: Zięba, 2005a, s. 9-19).

W toku prac nad projektem Traktatu o Unii Europejskiej (TUE) pojawiły się dwie koncepcje uregulowania relacji pomiędzy UE a UZE. Jedna z nich zakładała powstanie w ramach UE silnej WPZiB, a w przyszłości wspólnej polityki obronnej, mającej doprowadzić do ustanowienia wspólnej obrony. W ramach tej koncepcji UZE miała stać się integralną częścią UE. Natomiast druga koncepcja zakładała, że UZE zachowa 
w stosunku do UE autonomiczny charakter, NATO dalej pozostanie najważniejszą strukturą bezpieczeństwa Europy zachodniej, a WPZiB będzie funkcjonować w oparciu o mechanizmy współpracy międzyrządowej. Ostatecznie rozwiązania przyjęte w TUE opierały się na drugiej lansowanej przez Wielką Brytanię koncepcji. W Traktacie z Maastricht dokonano rozróżnienia między sprawami bezpieczeństwa, które stały się przedmiotem działania WPZiB, a sprawami obrony, które zastrzeżono do kompetencji UZE, stanowiącej integralną część rozwoju UE. Wzrost znaczenia UZE w procesie integracji europejskiej dokonał się wraz z wejściem w życie Traktatu amsterdamskiego. Mimo, że nie zdecydowano się na inkorporację UZE do UE to jednak w zakresie prowadzenia misji petersberskich (humanitarnych, ratowniczych, utrzymania pokoju, siłowego rozwiązywania kryzysów), UZE stała się narzędziem operacyjnym UE wykorzystywanym do prowadzenia działan militarnych. Ostateczne decyzje rozszerzające zakres działania WPZiB o wojskowe operacje reagowania kryzysowego zapadły na szczytach Rady Europejskiej w Kolonii (czerwiec 1999 r.), gdzie przyjęto wytyczne ustanawiające Europejską Politykę Bezpieczeństwa i Obrony (EPBiO) oraz w Helsinkach (grudzień 1999 r.), gdzie podjęto decyzję o tworzeniu sił zbrojnych UE. Decyzje te zostały usankcjonowane przez Traktat nicejski, który wyposażył UE w zdolność samodzielnego prowadzenia operacji petersberskich. Stało się to możliwe wskutek wcześniejszego podjęcia przez Radę Ministerialną UZE decyzji o przekazaniu UE swoich funkcji operacyjnych wraz ze strukturami (por. szerzej: Zięba, 2005b, s. 14-20). Ustanowienie EPBiO stało się możliwe w wyniku aktywności Francji i Niemiec, które to kraje będące motorem procesu integracji europejskiej zrozumiały, że UE bez silnej i jednolitej EPBiO nie będzie zdolna do kształtowania polityki międzynarodowej w oparciu o wyznawane przez siebie wartości. Jednakże poglądowi, że UE powinna być zarówno cywilną jak i wojskową siłą zdolną do przeprowadzenia operacji reagowania kryzysowego towarzyszył spór pomiędzy zwolennikami opcji europejskiej (Francja, Niemcy) a opcji atlantyckiej (Wielka Brytania) co do zakresu transferu suwerennych uprawnień państwa na szczebel EPBiO. O ile dla Niemiec priorytetem stało się tworzenie mechanizmów ponadnarodowych na poziomie EPBiO, to Wielka Brytania wyrażała duży sceptycyzm w stosunku do tej koncepcji (por. Hürsoy, 2002, s. 84-85). Ostatecznie zwyciężył pogląd, że EPBiO będzie miała przede wszystkim charakter międzyrządowy, co znalazło potwierdzenie w postanowieniach Traktatu z Lizbony, który wprowadził zmianę nazewnictwa tej polityki na Wspólną Politykę Bezpieczeństwa i Obrony (WPBiO). Rozszerzeniu uległy zadania realizowane w ramach WPBiO. Do katalogu wcześniej realizowanych tzw. zadań petersberskich dodano wspólne działania rozbrojeniowe, misje wojskowego doradztwa i wsparcia, operacje stabilizujące sytuacje pokryzysowe. Całość działań realizowanych w ramach WPBiO powinna przyczyniać się również do walki z terroryzmem i służyć wspieraniu państw trzecich $\mathrm{w}$ jego zwalczaniu. Zgodnie z postanowieniami sekcji 2 rozdziału 2 Tytułu 5 TUE, WPBiO stanowi integralną część WPZiB zapewniającą UE zdolność operacyjną do działań poza obszarem Unii. Decyzje dotyczące funkcjonowania WPBiO, w tym te odnoszące się do podjęcia misji, zgodnie z postanowieniami TUE przyjmowane są przez Radę stanowiącą jednomyślnie na wniosek Wysokiego Przedstawiciela Unii ds. Zagranicznych i Polityki Bezpieczeństwa lub Państwa Członkowskiego (zob. Wersja skonsolidowana Traktatu o Unii Europejskiej, art. 43-44). 
Należy podkreślić, że od samego początku powstania EPBiO/WPBiO budziła spory wśród jej twórców co do jej istoty i celu, który powinna osiąnąć. Podczas gdy we Francji postrzegano WPBiO jako narząazie politycznej integracji Europy, to w Wielkiej Brytanii definiowano tą politykę jako instrument zaprojektowany w celu poprawy europejskiego potencjału militarnego i przez to ożywienia funkcjonowania NATO. Jednakże wskutek doświadczeń UE w dziedzinie reagowania kryzysowego między innymi na Bałkanach, koncepcja funkcjonowania WPBiO uległa modyfikacji. Priorytetem działania WPBiO stały się nie operacje zarządzania kryzysowego o charakterze militarnym, ale długoterminowe operacje cywilne i aktywność w obszarze zwalczania terroryzmu i przeciwdziałania proliferacji broni masowego rażenia. Abstrahując od poglądów głoszących, że WPBiO jest logiczną konsekwencją rozwoju procesu integracji europejskiej lub zakładających, że stanowi ona tylko potwierdzenie chaotycznej ścieżki rozwoju polityki zagranicznej UE, należy zgodzić się z poglądem, że powstanie i funkcjonowanie WPBiO oznacza wzrost zdolności UE do interweniowania w sprawach międzynarodowego bezpieczeństwa. WPBiO stanowi praktyczne narzędzie interwencji poprzez rozwój organów tej polityki jak i koordynację oraz mobilizację wojskowych i cywilnych zdolności UE (por. Bickerton, Irondelle, Menon, 2011, s. 3-4).

Dominacja w ramach Wspólnej Polityki Bezpieczeństwa i Obrony (WPBiO) mechanizmów współpracy międzyrządowej mimo nazwy sugerującej jej uwspólnotowienie skutkuje tym, że głównymi podmiotami ją kreującymi są państwa członkowskie UE. Z tegoż powodu instytucje ponadnarodowe takie jak Parlament Europejski (PE) nie posiadają realnych uprawnień władczych w odniesieniu do WPBiO, a pełnią jedynie rolę organów doradczo-konsultacyjnych i opiniodawczych. Nie oznacza to jednak, że PE nie ma istotnego wpływu na kształt WPBiO. Dlatego głównym celem artykułu jest analiza stanowiska PE jako organu UE o statusie ustrojowym ponadnarodowym wobec ewolucji funkcjonowania WPBiO jak i najważniejszych zagadnień wchodzących w zakres tej polityki. Zamierzeniem autora jest weryfikacja hipotezy zakładającej, że PE w dziedzinie kształtowania polityki UE wobec WPBiO, która ma w przeważającej mierze charakter międzyrządowy odgrywa ze względu na eksponowanie swojej orientacji aksjologicznej (podkreślanie wagi wartości demokratycznych w polityce UE) rolę instytucji wpływu politycznego w odniesieniu do unijnego procesu decyzyjnego. Dlatego w celu wyjaśnienia roli PE w procesie kształtowania tej polityki, wśród przyjętych na potrzeby artykułu założeń metodologicznych zastosowano metodę badawczą, którą jest analiza decyzyjna. Należy podkreślić, że PE pomimo braku kompetencji decyzyjnych w obszarze WPBiO zwłaszcza po wejściu w życie Traktatu z Lizbony, który przekształcił UE w jednolitą strukturę prawnomiędzynarodową zaczął aspirować do odgrywania coraz większej roli w dziedzinie unijnej polityki bezpieczeństwa i obrony. Rola ta nie jest pochodną traktatowych prerogatyw PE, ale wynika przede wszystkim $\mathrm{z}$ bycia przez PE instytucją wpływu politycznego w stosunku do pozostałych organów UE, dzięki posiadaniu demokratycznej legitymacji i sprawowaniu funkcji kontrolnej (debaty parlamentarne, rezolucje, zalecenia, raporty). Podstawowym instrumentem wpływu są uchwalane przez ten organ rezolucje. Są to najliczniejsze dokumenty posiedzeń plenarnych Parlamentu, które dzielą się na legislacyjne (dotyczące projektów legislacyjnych) oraz nielegislacyjne - wszystkie pozostałe (Ogonowska, 2006, s. 18). 
PE próbuje wpływać na kształt i kierunki rozwoju WPBiO przede wszystkim poprzez przyjmowanie rezolucji nielegislacyjnych. Dokumenty te mimo, że nie stanowią elementu procesu decyzyjnego i pozbawione są mocy prawnie wiążącej pozwalają temu organowi wyrazić swoje stanowisko wobec WPBiO jak i pośrednio wpływać na jej kształt. Z uwagi na to, że funkcjonowanie UE cechuje się wysokim poziomem instytucjonalizacji, a dla autora kluczowym wyzwaniem badawczym w niniejszej publikacji jest analiza tekstów rezolucji przyjmowanych przez ponadnarodową instytucję jaką jest PE to na potrzeby artykułu zastosowano również metodę badawczą, którą jest analiza instytucjonalno-prawna (zob. szerzej: Chodubski, 2012, s. 25). Jej zastosowanie pozwala na poznanie opinii PE w kwestii rozwoju potencjału cywilnego jak i wojskowego UE w ramach WPBiO oraz udzielenie odpowiedzi na pytanie jaka jest preferowana przez PE koncepcja funkcjonowania tej polityki. Jednakże analizując postrzeganie WPBiO przez PE należy podkreślić że jest ono determinowane przez niechęć państw członkowskich decydujących o jej kształcie do zastosowania w tym obszarze integracji mechanizmów współpracy ponadnarodowej, co niewątpliwie ogranicza możliwości oddziaływania PE na funkcjonowanie unijnej polityki bezpieczeństwa i obrony.

\section{Parlament Europejski wobec wdrażania europejskiej strategii bezpieczeństwa oraz wspólnej polityki bezpieczeństwa i obrony}

Na proces budowy zdolności cywilnych i wojskowych UE istotny wpływ miało sformułowanie przez Radę Europejską (RE) w grudniu 2003 r. Europejskiej Strategii Bezpieczeństwa (ESB). Powstanie tego dokumentu było konsekwencją dostrzeżenia przez jednoczącą się Europę nowych asymetrycznych wymiarów bezpieczeństwa takich jak : migracje, terroryzm, bezpieczeństwo energetyczne, cyberbezpieczeństwo. W Strategii będącej zbiorem wyzwań i zagrożeń stojących przed UE w dziedzinie bezpieczeństwa wymieniono również cele strategiczne UE w tym obszarze jak i wnioski dla WPZiB oraz EPBiO (zob. szerzej: Koziej, 2011, s. 19-40). W związku z przyjęciem przez RE w grudniu 2003 r. ESB, PE w przyjętych rezolucjach z zadowoleniem przyjął zawarte w tym dokumencie całościowe podejście do pojęcia bezpieczeństwa. Mając na uwadze, że ESB jest częścią WPZiB i EPBO, w ramach których można zastosować całe spektrum działań politycznych UE obejmujących środki dyplomatyczne, ekonomiczne i polityki rozwojowej, PE podzielił pogląd RE, że najważniejsze zagrożenia dla światowego bezpieczeństwa to terroryzm, rozprzestrzenianie broni masowego rażenia, nierozwiązane konflikty regionalne, upadłe i upadające państwa oraz przestępczość zorganizowana, podkreślając zarazem, że stosowanie środków militarnych w celu eliminacji tych zagrożeń jest ostatecznością. W opinii PE najlepiej zapewnieniu bezpieczeństwa na świecie będzie służyć połączenie różnych potencjałów, programów i instrumentów pomocowych, będących w dyspozycji UE i jej członków. Ponadto PE w pełni zgadza się z celami strategicznymi UE zawartymi w ESB, jakimi sa: przeciwdziałanie zagrożeniom, budowanie bezpieczeństwa w sąsiedztwie Unii oraz wzmacnianie porządku międzynarodowego poprzez efektywne działania w ramach struktur wielostronnych, podkreśla także, że założenia ESB wykraczają daleko poza wojskowe aspekty unijnej polityki bezpieczeństwa i obrony. Dla PE kluczową kwestią dla prze- 
ciwdziałania zagrożeniom jest określenie zagrożeń o charakterze regionalnym i/lub globalnym pozwalające skutecznie wykorzystywać będące w jej posiadaniu instrumenty i zasoby. W przypadku zagrożeń regionalnych kluczowe znaczenie w opinii PE ma zapewnienie bezpieczeństwa w obszarach sąsiedzkich UE. Natomiast przeciwdziałanie zagrożeniom globalnym wymaga według opinii PE wykorzystania wielostronnych struktur międzynarodowych, których siłą napędową powinna być UE ściśle jednak współpracująca z ONZ, która powinna zachować prymat w ramach instytucji wielostronnych. Do tego jednak potrzebna jest zdaniem PE głęboka reforma ONZ, tak aby organizacja ta mogła sprostać w sferze bezpieczeństwa wyzwaniom XXI wieku. Dla PE kluczową kwestią w zapewnieniu bezpieczeństwa na świecie jest również konieczność nawiązywania i utrzymywania przez UE współpracy z innymi międzynarodowymi i regionalnymi organizacjami działającymi na rzecz światowego pokoju i bezpieczeństwa, ze szczególnym uwzględnieniem współpracy z OBWE (zob. Rezolucja Parlamentu Europejskiego z dnia 14 kwietnia 2005 r., s. 580).

Oznacza to, że zdaniem PE najlepszym sposobem osiagania celów UE w dziedzinie bezpieczeństwa zawartych w ESB jest skuteczny multilateralizm rozumiany jako instytucje i prawo międzynarodowe. Dlatego PE stoi na stanowisku, że w ramach WPBiO, „UE musi realizować swoje zadania przede wszystkim środkami cywilnymi i pokojowymi, a środki wojskowe stosować jedynie wtedy, gdy wszelkie starannie sprawdzone możliwości negocjacji ostatecznie okażą się bezowocne". Ponadto podczas realizacji zadań w ramach WPBiO stanowiącej filar procesu integracji europejskiej największy nacisk należy w opinii PE położyć na kwestie poszanowania praw człowieka i podstawowych wolności zarówno na terytorium UE, jak i poza nim. W tym celu UE musi dysponować odpowiednim potencjałem wojskowym i cywilnym, aby bronić się przed wszelkimi zagrożeniami dla bezpieczeństwa, zapewnić pokój i stabilność, przede wszystkim w swoim geograficznym sąsiedztwie, a także w innych częściach świata zgodnie z zasadami określonymi w Karcie ONZ. W opinii PE, Unia musi być zdolna do przeprowadzania interwencji humanitarnych i operacji ratunkowych, zapobiegania konfliktom i ich kontrolowania, wspierania demokracji i poszanowania praw człowieka oraz regionalnego i globalnego rozbrojenia (zob. Rezolucja Parlamentu Europejskiego z dnia 16 listopada 2006 r., s. 334). Będzie to możliwe tylko poprzez budowę zdolności wojskowych i cywilnych w ramach WPBiO, której rozwój pozwoli UE sprostać wyzwaniom i zagrożeniom sformułowanym w ESB. Tylko wtedy UE ma zdaniem PE szansę stania się istotnym podmiotem na arenie międzynarodowej i gwarantem bezpieczeństwa dysponującym rzeczywistą autonomią strategiczną. Optymalizacja WPBiO wymaga w opinii PE zmiany sposobu myślenia ze strony państw członkowskich, które zbyt często myślą o kwestiach bezpieczeństwa w kategoriach interesów narodowych, zaniedbując wspólnotową odpowiedzialność za ochronę interesów europejskich. Dlatego niezbędnym jest określenie wspólnych dla UE interesów bezpieczeństwa, ponieważ jedynie w wyniku ich określenia WPBiO stanie się polityką bardziej spójną i skuteczną. Według PE interesy bezpieczeństwa Unii obejmują poza tymi wymienionymi w ESB, ochronę jej obywateli i jej interesów na terytorium UE i poza nim, bezpieczeństwo jej sąsiedztwa, ochronę jej granic zewnętrznych i krytycznej infrastruktury, a także poprawę bezpieczeństwa przestrzeni wirtualnej, bezpieczeństwa dostaw energetycznych i szlaków żeglugi, ochronę systemów funkcjonujących 
w przestrzeni kosmicznej i ochronę przed skutkami zmian klimatu. Interesów bezpieczeństwa UE nie można w opinii PE postrzegać w oderwaniu od szerzej pojmowanej europejskiej struktury bezpieczeństwa, którą tworzą NATO, OBWE i międzynarodowe uzgodnienia takie jak traktaty o ograniczeniu rozwoju, testowania i rozmieszczania systemów antybalistycznych - ABM i o konwencjonalnych siłach zbrojnych w Europie -CFE (zob. Rezolucja Parlamentu Europejskiego z dnia 19 lutego 2009 r., s. 61).

Dla funkcjonowania WPBiO kluczową kwestią jest ułożenie relacji w dziedzinie bezpieczeństwa i obrony pomiędzy UE a NATO. PE jest zdania, że wzmocnienie zdolności cywilnych i wojskowych UE będzie korzystne również dla NATO, ponieważ przyczyni się do powstania synergii między obiema organizacjami. NATO dla PE pozostaje fundamentem zbiorowej obrony w Europie, a współpraca pomiędzy obiema organizacjami powinna zacieśniać istniejące między nimi partnerstwo strategiczne. Według PE, UE i NATO powinny zwłaszcza współpracować w dziedzinie zarządzania kryzysowego, szanując wzajemną autonomię w procesie decyzyjnym. PE zwraca również uwagę na konieczność unikania niepotrzebnego pokrywania się działań i zasobów obu organizacji oraz wzywa NATO do ścisłego ograniczenia rozbudowy potencjału cywilnego w celu uniknięcia dublowania się zadań. Ponadto PE zauważa, że istnienie wspólnej polityki obrony UE powoduje konieczność zintegrowania europejskich sił zbrojnych i wyposażenia ich we wspólne systemy uzbrojenia gwarantujące jednolitość i interoperacyjność. Dlatego krytykuje praktykę powszechnego dublowania się programów obronnych w Unii, a także politykę państw członkowskich w kwestii niedostatecznego udostępniania Unii swoich zasobów militarnych, co opóźnia proces formowania europejskich sił zbrojnych. W swoich rezolucjach PE „,wzywa państwa członkowskie do wsparcia Europejskiej Agencji Obrony jako agencji eksperckiej UE, której powierzono zadanie identyfikowania i rozwijania zdolności obronnych w dziedzinie zarządzania kryzysowego oraz promowania i umacniania europejskiej współpracy zbrojeniowej”. Domaga się debaty ze swoim udziałem w kwestii wdrażania postanowień Traktatu z Lizbony dotyczących klauzuli o wzajemnej pomocy w przypadku agresji na terytorium jednego z członków UE. Stoi na stanowisku, że klauzula ta ma charakter prawnie wiążący w przypadku zewnętrznej agresji na dowolne państwo członkowskie UE i nie uchybia roli NATO jako gwaranta bezpieczeństwa europejskiego (zob. Rezolucja Parlamentu Europejskiego z dnia 11 maja 2011 r., s. 51). Dlatego PE krytykuje brak zainteresowania decyzyjnych organów WPBiO, jak i państw członkowskich w kwestii wdrażania tej klauzuli w życie. Brak postępów w realizacji WPBiO spowodowany widoczną od wielu lat tendencją do obniżania wydatków przez państwa członkowskie na obronę i marginalizowania instrumentów i zdolności tej polityki grozi zdaniem PE upadkiem strategicznym UE, dlatego że drastycznie obniża jej zdolność do realizacji zadań w zakresie utrzymania pokoju, zapobiegania konfliktom i umacniania bezpieczeństwa międzynarodowego. Aby zapobiec degradacji strategicznej UE powinna dysponować efektywnymi stałymi siłami zbrojnymi (grupami bojowymi UE) o wysokiej gotowości do działań w sytuacjach kryzysowych złożonymi z sił powietrznych, morskich, cyberobrony i sił specjalnych. Ponadto w celu zapewnienia optymalnego działania WPBiO należy między innymi wzmacniać bazę przemysłową i technologiczną europejskiego sektora obrony, poszerzyć preferencję europejską o zakupy uzbrojenia, ustanowić polityczne i strategiczne wytyczne nakładające na państwa UE 
zobowiązania do rozwoju ich zdolności wojskowych, stworzyć podstawy wspólnego planowania począwszy od planowania strategicznego przez zamówienia publiczne aż po rozwój technologiczny, przyspieszyć realizację projektów np. łączności satelitarnej, cyberobrony czy jednolitej europejskiej przestrzeni powietrznej. Należy podkreślić, że PE dostrzega związek między rozwojem europejskiej bazy technologiczno-przemysłowej sektora obronnego stanowiącej podporę WPBiO a wzrostem gospodarczym, konkurencyjnością i powstawaniem nowych miejsc pracy (zob. Rezolucja Parlamentu Europejskiego z dnia 22 listopada 2012 r.; Rezolucja Parlamentu Europejskiego z dnia 21 listopada 2013 r.). Obok koordynowania i pobudzania inwestycji w technologie służące zarówno sektorowi militarnemu, jak i cywilnemu, powinno się w celu wzmocnienia zdolności WPBiO utworzyć zdaniem PE stały sztab operacyjny UE, do którego zadań należałoby planowanie operacyjne i prowadzenie operacji wojskowych. Sztab ten powinien wraz z Komórką Planowania i Prowadzenia Operacji Cywilnych zostać zintegrowany w ramach wspólnego unijnego sztabu zarządzania kryzysowego, który byłby odpowiedzialny za planowanie operacyjne, prowadzenie unijnych misji cywilnych, operacji wojskowych oraz misji związanych z reformą sektora bezpieczeństwa (zob. Rezolucja Parlamentu Europejskiego z dnia 23 listopada 2010 r., s. 7).

Zmianom WPBiO proponowanym przez PE towarzyszy chęć zapewnienia tej polityce silnej legitymacji demokratycznej. W licznych przyjmowanych stanowiskach PE podkreśla, że jest jedyną ponadnarodową instytucją, która ma prawo do demokratycznego nadzoru nad WPBiO, zwłaszcza po wejściu w życie Traktatu z Lizbony. Opowiada się również za współpracą z parlamentami państw członkowskich w dziedzinie WPBiO i dostosowaniem własnych struktur dla zapewnienia optymalnego nadzoru nad tą polityką (zob. Rezolucja Parlamentu Europejskiego z dnia 10 marca 2010 r.). Należy zaznaczyć, że domaganie się przez PE objęcia WPBiO demokratyczną kontrolą pozostaje jednak ciagle w sferze postulatywnej z racji wybitnie międzyrządowego charakteru tej polityki. Nadanie na poziomie ogólnoeuropejskim demokratycznej legitymacji WPBiO byłoby możliwe tylko w wyniku gruntownych zmian ustrojowych UE polegających na inkorporacji mechanizmów ponadnarodowych do obszaru WPBiO, co wskutek sprzeciwu państw członkowskich wydaje się w przewidywalnej perspektywie czasowej mało prawdopodobne.

\section{Parlament Europejski wobec problemu rozprzestrzeniania broni masowego rażenia}

Analizując stanowisko PE wobec problemu rozprzestrzeniania broni masowego rażenia (BMR) w kontekście funkcjonowania WPBiO należy uwzględnić zapisy ESB, według której problem ten stanowi potencjalnie najpoważniejsze zagrożenie dla bezpieczeństwa europejskiego, do którego UE przywiązuje najwyższą wagę. Należy ponadto podkreślić, że wszystkie państwa UE są stronami najważniejszych porozumień wielostronnych, które tworzą system nierozprzestrzeniania BMR. Porozumienia te to: Układ o nierozprzestrzenianiu broni jądrowej (NPT) z 1968 r., Konwencja o zakazie sprowadzania, badań, produkcji i gromadzenia zapasów broni bakteriologicznej (biologicznej) i toksycznej oraz ich zniszczeniu (BTWC) z 1972 r., Konwencja o zakazie pro- 
wadzenia badań, produkcji, gromadzenia i użycia broni chemicznej oraz jej niszczeniu (CWC) z 1993 r., a także Traktat o zakazie przeprowadzania prób nuklearnych (CTBC) z 1996 roku. W przypadku UE problem BMR jest o tyle istotny, że dwa państwa UE tj. Wielka Brytania i Francja są państwami posiadającymi broń jądrową w rozumieniu układu NPT. Ponadto broń taktyczna USA jest składowana na terytorium niektórych państw członkowskich. W przypadku problematyki rozprzestrzeniania BMR stanowisko PE jest jednoznaczne i bezkompromisowe oraz nastawione na eliminację zagrożeń związanych z występowaniem broni jądrowej. Dowodem na to jest sprzeciw PE odnoszący się do rozwoju przez USA broni jądrowej nowej generacji (tzw. mini bomby jądrowej), jak i wezwanie do działań zapobiegających dalszemu rozprzestrzenianiu pocisków balistycznych o zwiększonym zasięgu i celności poprzez rozwój i rozszerzanie członkostwa w mechanizmach kontroli zbrojeń, takich jak Reżim Kontrolny Technologii Rakietowych (MTCR) i haski kodeks postępowania. W opinii PE priorytety UE w obszarze BMR powinny być następujące: 1) zaangażowanie na szczeblu międzynarodowym promujące wdrażanie strategii UE w sprawie BMR; 2) położenie większego nacisku na inicjatywy rozbrojeniowe oraz na zagadnienia związane z nierozprzestrzenianiem BMR; 3) wzmocnienie układów wielostronnych składających się na system nierozprzestrzeniania; 4) położenie nacisku na nierozprzestrzenianie i zagrożenia związane z wykorzystaniem BMR przez terrorystów; 5) zapewnienie zasobów finansowych potrzebnych na wdrażanie strategii UE $\mathrm{w}$ sprawie BMR. W przypadku porozumień zawieranych przez UE z państwami trzecimi PE opowiada się za włączeniem do tych umów klauzul dotyczących nierozprzestrzeniania BMR oraz wzywa te państwa, a w szczególności te posiadające broń jądrową do nieudzielania pomocy ani poparcia krajom, które mogą starać się o nabycie tego rodzaju broni. Mając prawo zatwierdzania najważniejszych umów międzynarodowych PE opowiada się za uzależnieniem współpracy z UE od wypełniania przez stronę trzecią postanowień NPT. Ponadto PE postuluje zwiększenie zasobów UE umożliwiających wniesienie istotnego wkładu do reżimu inspekcyjnego ONZ kontrolującego nierozprzestrzenianie BMR. W przypadku Bliskiego Wschodu i obszaru śródziemnomorskiego PE stoi na stanowisku ustanowienia na tym obszarze strefy bez BMR oraz wzywa takie kraje jak Izrael, Indie i Pakistan aby stały się stronami NPT. Potwierdza również znaczenie ściślejszej współpracy ze Stanami Zjednoczonymi, w celu wzmocnienia międzynarodowego systemu układów i reżimów wymierzonych przeciwko rozprzestrzenianiu BMR, zapewnienia dokładnego wdrażania i przestrzegania postanowień, wspierania nierutynowych inspekcji, jak również uznania, że do zwalczania rozprzestrzeniania BMR mogą być potrzebne inne środki zgodne z prawem międzynarodowym. Opowiada się ponadto za szybkim podpisaniem i ratyfikowaniem CTBT (zob. Rezolucja Parlamentu Europejskiego z dnia 17 listopada 2005 r., s. 453). Analizując stanowisko PE w kwestii rozbrojenia nuklearnego należy podkreślić, że organ ten domaga się od potęg jądrowych stopniowego zmniejszania liczby głowic atomowych. Opowiada się ponadto za całkowitym zakazem używania broni chemicznej, biologicznej, a także min przeciwpiechotnych, amunicji kasetowej i amunicji zawierającej zubożony uran. Na uwagę zasługuje fakt, że PE sprzeciwiał się pierwotnym planom umieszczenia amerykańskiej tarczy antyrakietowej w Europie, opowiadając się za opracowaniem nowego podejścia w tej kwestii uwzględniającego interesy całej Europy i Rosji. Również zastanawiające jest podejście 
PE wobec atomowej obecności USA w Europie. W przyjętym stanowisku PE za strategiczny anachronizm uznaje składowanie w Europie taktycznej broni jądrowej, domagając się ograniczenia tego rodzaju broni oraz stopniowego jej usunięcia $\mathrm{z}$ terytorium europejskiego. W tej kwestii PE zaleca prowadzenie dialogu z Rosją (zob. Rezolucja Parlamentu Europejskiego z dnia 10 marca 2010 r., s. 77). Podsumowując stanowisko PE wobec zasadniczej kwestii WPBiO, jaką jest problem rozprzestrzeniania BMR można na podstawie szeregu rezolucji przez ten unijny organ przyjmowanych stwierdzić, że dla PE celem strategicznym jest całkowita likwidacja BMR. Jest to podejście dość kontrowersyjne, ale dobrze oddające dominujące w społeczeństwach europejskich nastroje pacyfistyczne przekładające się na postawę elit zachodnioeuropejskich. Postawy te znajdują szczególny oddźwięk na forum PE, które zdominowane jest przez zasady poprawności politycznej co jeszcze potęguje radykalizm przyjmowanych opinii w dziedzinie rozbrojenia. Ponadto niewiążący charakter wyrażanych przez PE stanowisk wpływa na ich treść, potęgując ich rozbrojeniowy wydźwięk.

\section{Podsumowanie}

Nie ulega wątpliwości, że skuteczność funkcjonowania UE na arenie międzynarodowej wymaga ścisłej współpracy państw członkowskich w dziedzinie bezpieczeństwa i obrony. Instrumentem tej współpracy jest WPBiO, która obejmuje założenia programowe, instytucje, cywilne i wojskowe zasoby oraz zdolności. Rozwój WPBiO umożliwia UE przeprowadzanie operacji petersberskich (akcji humanitarnych i ratowniczych, operacji utrzymywania pokoju oraz misji zarządzania kryzysowego), które mają miejsce poza granicami UE. Wbrew swojej nazwie WPBiO nie obejmuje zobowiązań w zakresie wspólnej obrony państw członkowskich i dlatego nie może być analizowana w kategoriach bezpieczeństwa militarnego. Polityka ta łączy przede wszystkim środki prewencyjne i wojskowe środki reagowania kryzysowego z cywilnymi dając UE szansę stania się kompleksowym aktorem stosunków międzynarodowych (Zajączkowski, 2009, s. 50-51). Ważność tej polityki dla potwierdzania tożsamości UE na arenie międzynarodowej sprawia, że WPBiO staje się przedmiotem szczególnego zainteresowania PE. Oceniając stanowisko PE wobec zasadniczych kwestii wchodzących w zakres WPBiO należy zauważyć, że z formalno-traktatowego punktu widzenia organ ten nie jest pełnoprawnym podmiotem współdecydującym o kształcie tej polityki. Wynika to z faktu, że PE jako instytucja o charakterze ponadnarodowym nie posiada kompetencji decyzyjnych $\mathrm{w}$ odniesieniu do zdominowanej przez mechanizmy współpracy międzyrządowej WPBiO stanowiącej integralną część WPZiB. Oznacza to, że w odniesieniu do zagadnień wchodzących w zakres WPBiO rola PE sprowadza się do bycia przede wszystkim instytucją o charakterze opiniodawczym i konsultacyjnym. Podstawowym instrumentem wyrażania przez PE opinii w dziedzinie WPBiO są przyjmowane na jego forum rezolucje nielegislacyjne. Mimo, że pozbawione są one mocy prawnie wiążącej mają jednak istotne znaczenie polityczne. Zawierają one poglądy PE, które $\mathrm{z}$ racji tego, że jest to jedyna instytucja unijna mająca demokratyczną legitymację, która z założenia reprezentuje społeczeństwa Europy muszą być w mniejszym lub większym stopniu uwzględniane przez pozostałe organy UE, jak i państwa członkowskie. PE wy- 
rażając swoje stanowisko wobec najważniejszych zagadnień WPBiO może powoływać się na wolę europejskiej opinii publicznej, zarazem poprzez rezolucje ją kształtując. Pozwala mu to odgrywać w stosunku do Rady UE, która jest najważniejszym organem decyzyjnym WPBiO rolę instytucji wpływu politycznego, której znaczenie wykracza daleko poza jej traktatowe kompetencje. Jednakże cel nakreślony w wielu rezolucjach przez PE zakładający przekształcenie $\mathrm{WPBiO} w$ politykę funkcjonującą również w oparciu o mechanizmy współpracy ponadnarodowej i poddanej kontroli parlamentarnej nie został jeszcze osiagnięty. Pomimo zmian dokonanych w Traktacie lizbońskim rola PE w kreowaniu WPBiO nie wzrosła zgodnie $\mathrm{z}$ jego oczekiwaniami. Ujednolicenie stosunków zewnętrznych UE poprzez zlikwidowanie filarowości UE nie doprowadziło do zniesienia szczególnego - międzyrządowego charakteru WPBiO. Skutkiem takich rozwiązań traktatowych jest niemożność odgrywania przez PE takiej roli w obszarze WPBiO, która by odpowiadała znaczeniu tego organu w systemie instytucjonalnym UE. Dlatego podstawowym instrumentem realizacji polityki PE w obszarze WPBiO pozostają rezolucje. W dokumentach tych PE opowiada się za rozwojem silnej, jednolitej WPBiO opartej na zdefiniowanych europejskich interesach bezpieczeństwa. Wypracowaniu ogólnoeuropejskiego podejścia do zagadnień wchodzących w zakres WPBiO powinien towarzyszyć rozwój potencjału wojskowego, jak i cywilnego UE zdolnego gwarantować bezpieczeństwo, jak i reagować na zaistniałe sytuacje kryzysowe, zwłaszcza w najbliższym sąsiedztwie. Jednakże, co warto podkreślić, PE mimo że opowiada się za wzrostem strategicznego znaczenia UE we współczesnym świecie nie uważa, że UE powinna w międzynarodowej architekturze bezpieczeństwa odgrywać rolę zbliżoną do USA. Wynika to z przekonania PE, że do zapewnienia bezpieczeństwa należy dążyć przede wszystkim wykorzystując środki cywilne, a nie wojskowe, które winny być używane w ostateczności i stania na stanowisku, że NATO powinno pozostać fundamentem zbiorowej obrony w Europie. Ponadto, analizując stanowisko PE w obszarze WPBiO, należy podkreślić przywiązanie PE do międzynarodowego multilateralizmu. W jego opiniach zauważalny jest pogląd, że kluczową rolę w zapewnieniu bezpieczeństwa i przeciwdziałaniu takim zagrożeniom jak np. rozprzestrzenianie broni masowego rażenia czy terroryzm powinny odgrywać wielostronne struktury międzynarodowe na czele z ONZ. Rolą WPBiO winno być zapewnienie UE autonomicznej zdolności do działania w sferze militarnej, jak i cywilnej pozwalającej we współpracy z innymi organizacjami międzynarodowymi sprostać wyzwaniom w dziedzinie bezpieczeństwa. Na obecnym poziomie rozwoju WPBiO wdrożenie w życie opinii PE w tej dziedzinie uzależnione jest od decyzji podejmowanych przez organy międzyrządowe UE tj. Radę Europejską i Radę UE. Ażeby PE stał się pełnoprawnym w stosunku do tych organów podmiotem kształtującym WPBiO musiałaby zostać zmaterializowana koncepcja ustanowienia ponadnarodowej unii politycznej, w ramach której możliwe by było prowadzenie polityki zagranicznej poza instytucjami państwa narodowego. W przeciwnym razie realne uwspólnotowienie WPBiO oznaczające transfer kompetencji władczych $\mathrm{w}$ tej dziedzinie polityki na szczebel unijnych instytucji ponadnarodowych nie zostanie zrealizowane i PE pozostanie w tym obszarze integracji przede wszystkim organem o charakterze konsultacyjno-opiniodawczym. 


\section{Bibliografia}

Bickerton Ch. J., Irondelle B., Menon A. (2011), Security Co-operation beyond the Nation - State: The EU's Common Security and Defence Policy, „Journal of Common Market Studies”, vol. 49 , nr 1.

Chodubski A. (2012), Teorie i metody badań europeistycznych, w: Teorie w studiach europejskich. $W$ kierunku nowej agendy badawczej, red. J. Ruszkowski, L. Wojnicz, Instytut Politologii i Europeistyki US, Instytut Europeistyki UW, Szczecin-Warszawa.

Hürsoy S. (2002), The New Security Concept and German-French Approaches to the European Pillar of Defence 1990-2000, Marburg.

Koziej S. (2011), Potrzeba nowelizacji strategii bezpieczeństwa Unii Europejskiej, „Bezpieczeństwo Narodowe", nr 20.

Ogonowska A. (2006), Dokumenty i publikacje instytucji i organów Unii Europejskiej, „Zeszyty OIDE”, nr 6.

Rezolucja Parlamentu Europejskiego z dnia 14 kwietnia 2005 r. w sprawie Europejskiej Strategii Bezpieczeństwa, Dz. U. C 33 E z 9.02.2006.

Rezolucja Parlamentu Europejskiego z dnia 16 listopada 2006 r. w sprawie wdrożenia Europejskiej Strategii Bezpieczeństwa w kontekście Europejskiej Polityki Bezpieczeństwa i Obrony (EPBO), Dz. U. C 314 E z 21.12.2006.

Rezolucja Parlamentu Europejskiego z dnia 19 lutego 2009 r. w sprawie europejskiej strategii bezpieczeństwa i europejskiej polityki bezpieczeństwa i obrony, Dz. U. C 76 E z 25.03.2010.

Rezolucja Parlamentu Europejskiego z dnia 11 maja 2011 r. w sprawie rozwoju wspólnej polityki bezpieczeństwa i obrony po wejściu w życie Traktatu z Lizbony, Dz. U. C 377 E z 7.12.2012.

Rezolucja Parlamentu Europejskiego z dnia 22 listopada 2012 r. w sprawie wdrażania wspólnej polityki bezpieczeństwa i obrony (na podstawie sprawozdania rocznego Rady dla Parlamentu Europejskiego na temat wspólnej polityki zagranicznej $i$ bezpieczeństwa), P7_TA(2012)0455.

Rezolucja Parlamentu Europejskiego z dnia 21 listopada 2013 r. w sprawie wdrażania wspólnej polityki bezpieczeństwa i obrony (na podstawie sprawozdania rocznego Rady dla Parlamentu Europejskiego na temat wspólnej polityki zagranicznej $i$ bezpieczeństwa), P7_TA(2013)0513.

Rezolucja Parlamentu Europejskiego z dnia 23 listopada 2010 r. w sprawie wspótpracy cywilno-wojskowej i rozwoju potencjatu cywilno-wojskowego, Dz. U. C 99 E z 3.04.2012.

Rezolucja Parlamentu Europejskiego z dnia 10 marca 2010 r. w sprawie wdrażania europejskiej strategii bezpieczeństwa oraz wspólnej polityki bezpieczeństwa i obrony, Dz. U. C 349 E z 22.12.2010.

Rezolucja Parlamentu Europejskiego z dnia 17 listopada 2005 r. w sprawie nierozprzestrzeniania broni masowego rażenia: rola Parlamentu Europejskiego, Dz. U. C 280 E z dnia 18.11.2006.

Rezolucja Parlamentu Europejskiego z dnia 10 marca 2010 r. w sprawie Uktadu o nierozprzestrzenianiu broni jadrowej, Dz. U. C 349 E z dnia 22.12.2010.

Wersja skonsolidowana Traktatu o Unii Europejskiej, Dz. U. C 326 z 26.10.2012.

Zajączkowski K. (2009), Unia Europejska jako aktor globalny - aspekty polityczno-obronne, „Studia Europejskie", nr 1.

Zięba R. (2005a), Europejska Polityka Bezpieczeństwa i Obrony, Warszawa.

Zięba R. (2005b), Wspólna Polityka Zagraniczna i Bezpieczeństwa Unii Europejskiej, Warszawa. 


\section{Streszczenie}

Artykuł przedstawia stanowisko Parlamentu Europejskiego (PE) wobec rozwoju i najważniejszych priorytetów WPBiO UE po jej rozszerzeniu w 2004 r. na Wschód. Kwestie wchodzące w zakres WPBiO nie należą do tradycyjnych obszarów integracji, gdyż dotyczą problematyki bezpieczeństwa i obrony stanowiącej istotę suwerenności państwa narodowego pozostającego do dnia dzisiejszego najważniejszym podmiotem w procesie integracji europejskiej. Ma to zasadniczy wpływ na funkcjonowanie WPBiO, która wciąż pozostaje polityką, w ramach której dominują międzyrządowe mechanizmy współpracy. Powoduje to, że rola PE w kształtowaniu WPBiO jest ograniczona i sprowadza się przede wszystkim do wyrażania zawartych w rezolucjach niewiążących opinii. Jednakże przyjmowane przez PE rezolucje w sprawie WPBiO mimo, że nie wiążą pod względem prawnym mają swoją istotną wagę polityczną. Wynika to z faktu bycia przez PE jedyną ponadnarodową instytucją unijną mającą demokratyczną legitymację i mogącą sobie rościć prawo do sprawowania parlamentarnej kontroli nad WPBiO. Istotą stanowiska PE wobec WPBiO jest domaganie się włączenia mechanizmów ponadnarodowych do obszaru tej polityki, co zagwarantowałoby jej uwspólnotowienie w przyszłości. Jednakże postulowana przez PE budowa jednolitej wspólnotowej polityki bezpieczeństwa i obrony może zostać zrealizowana tylko poprzez przekształcenie UE w strukturę o znamionach federacji.

Słowa kluczowe: Parlament, Unia, bezpieczeństwo, obrona, rozszerzenie

\section{The position of the European Parliament on the Common Security and Defence Policy of the enlarged $\mathbf{E U}$}

\section{Summary}

This paper outlines the position of the European Parliament on the development and top priorities of EU CSDP after the 2004 eastern enlargement. The issues the CSDP is concerned with are not typical integration concerns, constituting the core of sovereignty of nation-states which continue to be the most important entity in the EU integration process. This fact significantly affects the way the CSDP functions, as it continues to be a policy dominated by intergovernmental cooperation mechanisms. Therefore, the role of the EP in the shaping of the CSDP is limited and, in fact, does not extend beyond expressing non-binding opinions stipulated in resolutions. And yet, the resolutions regarding the CSDP adopted by the EP, though legally non-binding, do carry political significance. This results from the fact that the EP is the only supranational EU institution that provides for the Union's democratic legitimacy, and is entitled to claim rights to exercise parliamentary control over the CSDP. Most importantly, at the core of the EU parliament's position is the demand that the CSDP incorporates supranational mechanisms into its policy, which would ensure its 'unionising' in the future. However, the building of a uniform security and defence policy, propounded by the EP can be implemented only through the transformation of the EU into a structure with features of a federation.

Key words: Parliament, Union, security, defence, expansion 